University of Nebraska - Lincoln

DigitalCommons@University of Nebraska - Lincoln

Uniformed Services University of the Health

Sciences

U.S. Department of Defense

1982

\title{
Production of Shigella dysenteriae Type 1-Like Cytotoxin by Escherichia coli
}

\author{
Alison D. O'Brien \\ Uniformed Services University of the Health Sciences, alison.obrien@usuhs.edu \\ Gerald D. LaVeck \\ Uniformed Services University of the Health Sciences \\ Michael R. Thompson \\ Uniformed Services University of the Health Sciences \\ Samuel B. Formal \\ Walter Reed Institute of Research
}

Follow this and additional works at: https://digitalcommons.unl.edu/usuhs

Part of the Medicine and Health Sciences Commons

O'Brien, Alison D.; LaVeck, Gerald D.; Thompson, Michael R.; and Formal, Samuel B., "Production of Shigella dysenteriae Type 1-Like Cytotoxin by Escherichia coli" (1982). Uniformed Services University of the Health Sciences. 111.

https://digitalcommons.unl.edu/usuhs/111

This Article is brought to you for free and open access by the U.S. Department of Defense at DigitalCommons@University of Nebraska - Lincoln. It has been accepted for inclusion in Uniformed Services University of the Health Sciences by an authorized administrator of DigitalCommons@University of Nebraska Lincoln. 


\title{
Production of Shigella dysenteriae Type 1-Like Cytotoxin by Escherichia coli
}

\author{
Alison D. O'Brien, Gerald D. LaVeck, \\ Michael R. Thompson, ${ }^{*}$ and Samuel B. Formal
}

\author{
From the Department of Microbiology, Uniformed Services \\ University of the Health Sciences, Bethesda, Maryland; and \\ the Walter Reed Army Institute of Research, \\ Washington, D.C.
}

\begin{abstract}
Strains of Escherichia coli previously implicated or proven to be causes of diarrhea were examined for production of a toxin similar to that of Shigella dysenteriae type 1 (Shiga). Organisms grown in an iron-depleted broth were lysed by pressure disruption followed by ultracentrifugation. Saline-dialyzed extracts were tested for cytotoxic effects on HeLa cells that were neutralizable with antiserum to Shiga toxin. Among the $13 E$. coli strains so analyzed, 11 made a Shiga-like cytotoxin in levels ranging from trace (two avirulent isolates) to amounts equivalent to $S$. dysenteriae type 1 (two noninvasive strains that did not make $E$. coli heat-labile or -stable enterotoxins but were isolated from infants with diarrhea). As with extracts of Shiga toxin, lysates of these $E$. coli strains that produced high levels of Shiga-like toxin were enterotoxic for rabbits, paralytic and lethal for mice, and inhibited protein synthesis in HeLa cells. Thus, these data suggest that Shiga-like toxin may be another heretofore undiscovered factor in the pathogenesis of diarrhea caused by some $E$. coli strains.
\end{abstract}

Two mechanisms have been described by which Escherichia coli can cause diarrheal disease in humans and animals [1]. Some strains colonize the small bowel and cause fluid secretion by elaboration of heat-labile (LT) and/or heat-stable (ST) enterotoxins [2-4]. In contrast to these noninvasive, enterotoxic organisms, certain strains of $E$. coli penetrate and multiply within colonic epithelial cells $[1,5]$ and are able to produce keratoconjunctivitis in guinea pigs (the Séreny test) [6]. Infection with these enteroinvasive strains may cause symptoms that mimic those seen in patients with shigellosis $[1,5,7]$. That $E$. coli must be capable of mediating gastroenteritis by other means is indicated by the finding that some strains associated with diarrheal disease produce no detectable LT or ST and are Séreny test-negative [8-10]. Instead, such organisms have been shown by electron microscopic studies to displace

Received for publication April 30, 1982, and in revised form July 29, 1982.

The opinions or assertions contained herein are the private views of the authors and should not be construed as official or as necessarily reflecting the views of the Uniformed Services University of the Health Sciences or the Department of Defense.

This study was supported by grant no. R07312 from the Uniformed Services University of the Health Sciences.

Please address requests for reprints to Dr. Alison O'Brien, Department of Microbiology, Uniformed Services University of the Health Sciences, 4301 Jones Bridge Road, Bethesda, Maryland 20814.

* Present address: Division of Digestive Diseases, University of Cincinnati School of Medicine, Cincinnati, Ohio. the microvilli and adhere to the cell membrane of intestinal epithelial cells. Invasion of the epithelial cells occurs but apparently with less frequency and perhaps by a mechanism different from that of shigellae [10-12].

In a preliminary report [13] we indicated that some of these LT-negative, ST-negative, Séreny test-negative organisms can produce a toxin like that of Shigella dysenteriae type 1 (Shiga) - that is, the cytotoxicity is neutralizable by antiserum to Shiga toxin - and suggested that this toxin could be responsible for the diarrhea-evoking potential of these microbes. Subsequently, we had difficulty in consistently reproducing these findings. However, we recently observed [14] that the yield of Shiga toxin can be increased if the organisms are grown in alkaline medium or medium pretreated with the iron-chelating resin Chelex $^{\circledR}$ (Bio-Rad, Richmond, Calif.). The purpose of the present investigation was to use these improved culture methods to verify that some $E$. coli isolates do indeed produce Shiga-like toxins. A second interdependent aim of the study was to determine the relationship between the pathogenic character (for example, enteroinvasive or enterotoxic) of a strain of $E$. coli and its capacity to elaborate Shiga-like toxin.

\section{Materials and Methods}

Bacterial strains. The various bacteria examined for production of Shiga-like toxin are described in table 1. 
Table 1. Characteristics of bacterial strains examined in a study of production of Shigella dysenteriae type 1-like cytotoxin.

\begin{tabular}{|c|c|c|c|c|c|c|c|c|}
\hline \multirow[b]{2}{*}{$\begin{array}{l}\text { Organism, } \\
\text { strain (serotype) }\end{array}$} & \multirow[b]{2}{*}{ Source } & \multirow[b]{2}{*}{$\begin{array}{c}\text { Diarrhea } \\
\text { in human } \\
\text { volunteers }\end{array}$} & \multicolumn{4}{|c|}{ Culture supernatant } & \multirow[b]{2}{*}{$\begin{array}{l}\text { Séreny } \\
\text { test }^{\dagger}\end{array}$} & \multirow[b]{2}{*}{ Reference } \\
\hline & & & $\begin{array}{l}\text { Rabbit } \\
\text { ileal } \\
\text { loop test }\end{array}$ & $\begin{array}{l}\text { Heat-labile } \\
\text { enterotoxin }\end{array}$ & $\begin{array}{l}\text { Heat-stable } \\
\text { enterotoxin a }\end{array}$ & $\begin{array}{l}\text { Water } \\
\text { adsorption* }\end{array}$ & & \\
\hline $\begin{array}{l}\text { Escherichia coli } \\
\text { K12 strain } 1133 \\
\text { (nontypable) }\end{array}$ & $\begin{array}{l}\text { Laboratory strain, } \\
\text { avirulent }\end{array}$ & NT & Negative & Negative & Negative & NT & Negative & 15 \\
\hline HS (nontypable) & Healthy adult & Negative & Negative & Negative & Negative & NT & Negative & 1,9 \\
\hline $\begin{array}{c}\mathrm{E} 851 / 71(\mathrm{O} 142: \\
\mathrm{K} 86: \mathrm{H} 6)^{\ddagger}\end{array}$ & $\begin{array}{l}\text { Epidemic infant } \\
\text { diarrhea }\end{array}$ & Positive & Negative & Negative & Negative & Positive & Negative & $9,16,17$ \\
\hline $\begin{array}{c}\text { E74/68 (O128: } \\
\text { K67:H2) }\end{array}$ & $\begin{array}{l}\text { Epidemic infant } \\
\text { diarrhea }\end{array}$ & Negative & Negative & Negative & Negative & Positive & Negative & $9,16,17$ \\
\hline $12801 / 0(\mathrm{O} 114) \ddagger$ & $\begin{array}{l}\text { Sporadic infant } \\
\text { diarrhea }\end{array}$ & Positive & Negative & Negative & Negative & NT & Negative & $\S$ \\
\hline $\mathrm{NC}(\mathrm{O} 125: \mathrm{H} 21)^{\ddagger}$ & Infant diarrhea & NT & Negative & Negative & Negative & NT & Negative & 10 \\
\hline $\mathrm{H} 30(\mathrm{O} 26)^{\ddagger}$ & Infant diarrhea & NT & Negative & Negative & Negative & NT & Negative & 18 \\
\hline $\begin{array}{l}\text { S-22-1 (O103: } \\
\text { H2:K?) }\end{array}$ & Infant diarrhea & NT & NT & Negative & Negative & NT & Negative & 19 \\
\hline RDEC-1 (O15) & Rabbit diarrhea & NT & Negative & Negative & Negative & NT & Negative & 8 \\
\hline $\begin{array}{l}\text { H10407 } \\
\quad(O 78: H 11: K 2)\end{array}$ & Adult diarrhea & NT & Positive & Positive & Positive & Positive & Negative & 17,20 \\
\hline E2531 (O25:K98) & Adult diarrhea & NT & NT & Positive & Negative & NT & Negative & 21 \\
\hline $\begin{array}{l}\text { TD } 514 C_{1} \\
\text { (unknown) }\end{array}$ & Adult diarrhea & NT & NT & Negative & Positive & NT & Negative & 22 \\
\hline $\begin{array}{c}4608-58-899 \\
(O 143)\end{array}$ & Adult diarrhea & Positive & Negative & Negative & Negative & NT & Positive & 1 \\
\hline $\begin{array}{l}S . \text { dysenteriae } \\
\text { type } 1,6 \mathrm{OR}\end{array}$ & $\begin{array}{l}\text { Rough avirulent } \\
\text { laboratory strain }\end{array}$ & NT & Positive & Negative & Negative & Negative & Negative & $14,23,24$ \\
\hline $\begin{array}{l}\text { Shigella flexneri } \\
\text { type 2a, M4243 }\end{array}$ & $\begin{array}{l}\text { Adult dysentery, } \\
\text { passaged in } \\
\text { monkeys }\end{array}$ & Positive & Negative & NT & NT & NT & Positive & 1,25 \\
\hline $\begin{array}{l}\text { Salmonella typhi- } \\
\text { murium, W118 }\end{array}$ & $\begin{array}{l}\text { Mouse typhoid, } \\
\text { virulent in } \\
\text { monkeys }\end{array}$ & NT & Negative & NT & NT & NT & Negative & 26,27 \\
\hline $\begin{array}{c}\text { Pseudomonas } \\
\text { aeruginosa }\end{array}$ & Burn patient & NT & NT & NT & NT & NT & NT & None \\
\hline
\end{tabular}

NOTE. $\quad$ NT $=$ not tested.

* Inhibition of water adsorption in rat jejuna.

$\dagger$ Enteroinvasive (causes keratoconjunctivitis in guinea pigs) in Séreny test [6].

$\ddagger$ Enteropathogenic E. coli of classical serotype (O26, O55, O86, O111, O114, O125, O126, O127, O128, or O142).

$\S$ R. E. Black and M. M. Levine, personal communication.

Culture medium. Iron-depleted syncase broth, briefly described in a previous report [14], was prepared as follows. Ten grams of certified casamino acids (Difco Laboratories, Detroit), $1.17 \mathrm{~g}$ of $\mathrm{NH}_{4} \mathrm{Cl}, 5 \mathrm{~g}$ of $\mathrm{KH}_{2} \mathrm{PO}_{4}, 5 \mathrm{~g}$ of $\mathrm{Na}_{2} \mathrm{HPO}_{4}$, and 1 $\mathrm{ml}$ of trace salts $\left(5 \% \mathrm{MgSO}_{4}\right.$ and $0.5 \% \mathrm{MnCl}_{2}$ in $0.001 \mathrm{~N} \mathrm{H}_{2} \mathrm{SO}_{4}$ ) were dissolved in 1 liter of quartz- distilled water, and the $\mathrm{pH}$ was adjusted to 8.0 with $2 \mathrm{~N} \mathrm{NaOH}$. Next, $20 \mathrm{~g}$ of Chelex 100 (100-200 mesh; sodium form; Bio-Rad) was added per liter of solution, the broth-resin mixture was incubated for $2 \mathrm{hr}$ at $4 \mathrm{C}$ with stirring, and the iron-chelating beads were removed by filtration through a large Büchner funnel lined with two sheets of filter 
paper (Whatman no. 1; Arthur H. Thomas, Philadelphia). The medium was then distributed into flasks precleaned with cleaning solution (RBS-35; Pierce Chemical Co., Rockford, Ill.), a surfaceactive agent that removes iron and other contaminants from glassware. The broth was sterilized for $20 \mathrm{~min}$ at $121 \mathrm{C}$ in an autoclave and then allowed to cool, and a sterile solution of $0.2 \%$ glucose, $0.004 \%$ L-tryptophan, and $0.002 \%$ nicotinic acid that had been treated with $2 \%$ Chelex was added.

To conserve Chelex, the resin was regenerated by the following method. The used beads were scraped from the Whatman filter paper, boiled in 10 volumes of $1 \mathrm{~N} \mathrm{HCl}$, and washed five times in distilled water. The acid-treated Chelex was then boiled in 10 volumes of $1 \mathrm{~N} \mathrm{NaOH}$ and washed five times in distilled water, and the excess water was removed by suction through a fritted glass funnel.

Preparation of bacterial extracts. Organisms were incubated for $48 \mathrm{hr}$ with shaking $(260 \mathrm{rpm})$ at $37 \mathrm{C}$. The sample size was 3 liters, distributed as 2 liters and 1 liter in 4-liter and 2-liter flasks, respectively. The bacteria were harvested by centrifugation at $10,000 \mathrm{~g}$ at $4 \mathrm{C}$ for $20 \mathrm{~min}$ and washed twice in $0.85 \% \mathrm{NaCl}$ before the wet weight was determined. Weights ranged from 2 to $4.0 \mathrm{~g} /$ liter of medium, and larger bacterial yields generally indicated incomplete iron depletion of the broth and, consequently, reduced toxin production. The organisms were then resuspended in $20 \mathrm{ml}$ of buffer $\left(0.05 \mathrm{M} \mathrm{KCl}, 0.01 \mathrm{M} \mathrm{MgCl}_{2}\right.$, and $0.02 \mathrm{M}$ Tris at $\mathrm{pH}$ 7.4) and disrupted by two passages through a French pressure cell at 15,000 psi. Lysates were then subjected to ultracentrifugation at $100,000 \mathrm{~g}$ for $70 \mathrm{~min}$ and supernatants were dialyzed against $0.85 \% \mathrm{NaCl}$ at $4 \mathrm{C}$. The protein content of these extracts was estimated spectrophotometrically [28].

Biologic and immunologic assays. Cytotoxicity tests were performed with HeLa cells (Walter Reed Army Institute of Research, Washington, D.C.) by the method of Gentry and Dalrymple [29]. Neutralization tests were done by mixing equal volumes of serially diluted rabbit antiserum to Shiga toxin or preimmunization rabbit serum with $1050 \%$ cytotoxic doses of toxin contained in filtered bacterial extracts and then incubating the mixtures for $1 \mathrm{hr}$ at $37 \mathrm{C}$, followed by overnight incubation at $4 \mathrm{C}$. Rabbit antiserum to Shiga toxin was elicited against purified Shiga toxin [23] by a previously described immunization protocol [23].
A 0.1-ml aliquot of each toxin-serum mixture was then added to HeLa cells. All dilutions were prepared in Eagle's minimal essential medium with Earle's balanced salts (HEM Research, Rockville, Md.) plus $2 \mathrm{~mm}$ L-glutamine, $10 \%$ fetal bovine serum (Flow Laboratories, McLean, Va.), 100 units of penicillin $\mathrm{G} / \mathrm{ml}$, and $100 \mu \mathrm{g}$ of gen$\operatorname{tamicin} / \mathrm{ml}$.

Other analyses performed on some bacterial extracts included tests for enterotoxic activity by the rabbit ileal loop assay [30] and assessments of the paralytic and lethal activity for mice [25]. In addition, the technique of Brown et al. was used to quantitate the effects of certain cytotoxic extracts on protein synthesis in HeLa cells [31]. Finally, the antigenic relationships among some of the toxins contained in extracts were assessed by immunodiffusion against rabbit antiserum to Shiga toxin. Immunodiffusion plates were prepared as described [23].

\section{Results}

Bacterial cell extracts and culture supernatants from 13 strains of $E$. coli that had been grown in iron-depleted medium were tested for cytotoxic effects on HeLa cells that were neutralizable with antiserum to Shiga toxin. These particular isolates were selected because they were well-characterized and represented a pathogenic spectrum that ranged from avirulent to virulent by an established diarrhea-evoking mechanism (LT-positive, ST-positive, or enteroinvasive) or by undefined means (LT-negative, ST-negative, and Séreny testnegative). Positive controls for the study included lysates and culture supernatants of $S$. dysenteriae type 1 strain 60R, which produces high levels of Shiga toxin $[14,23,24]$, as well as a strain of Shigella flexneri type $2 \mathrm{a}$, which produces Shigalike toxin [25]. Two other bacterial species were included in this investigation: Salmonella typhimurium (another Enterobacteriaceae) and the unrelated gram-negative microbe, Pseudomonas aeruginosa. Some pertinent characteristics of these microbes are listed in table 1.

The results of the cytotoxicity evaluations are shown in table 2 . The organisms were arbitrarily grouped into four categories according to the effects of the bacterial extract on HeLa cells. Category 1 contained those isolates that made cellassociated cytotoxins that were not neutralized by rabbit antiserum to Shiga toxin, such as $P$. aeru- 
Table 2. Production of cytotoxins, categorized by similarity to the toxin of Shigella dysenteriae type 1 (Shiga), by various bacterial strains.

\begin{tabular}{|c|c|c|c|c|c|}
\hline \multirow[b]{2}{*}{ Category } & \multirow[b]{2}{*}{ Toxin production } & \multirow[b]{2}{*}{ Bacteria } & \multicolumn{2}{|c|}{ Cytotoxicity for HeLa cells } & \multirow{2}{*}{$\begin{array}{c}\text { Cytotoxicity } \\
\text { neutralized by rabbit } \\
\text { antiserum to Shiga } \\
\text { toxin (titer)* }\end{array}$} \\
\hline & & & $\begin{array}{c}\text { CDso } / \mathrm{ml} \\
\text { of culture } \\
\text { supernatant }\end{array}$ & $\begin{array}{c}\mathrm{CD}_{s 0} / \mathrm{mg} \\
\text { of protein in } \\
\text { bacterial extract }\end{array}$ & \\
\hline \multirow[t]{4}{*}{1} & Cytotoxin not Shiga-like & Escherichia coli & & & \\
\hline & & E2531 & ND & 9 & No \\
\hline & & $\mathrm{NC}$ & ND & 15 & No \\
\hline & & Pseudomonas aeruginosa & ND & 60 & No \\
\hline \multirow[t]{3}{*}{2} & Trace levels of Shiga-like & E. coli & & & \\
\hline & toxin $\left(\leqslant 10 \mathrm{CD}_{s 0} / \mathrm{mg}\right.$ of & K12 (strain 1133) & ND & 2 & Yes $(1: 3,200)$ \\
\hline & bacterial extract) & HS & ND & 10 & Yes $(1: 6,400)$ \\
\hline \multirow[t]{12}{*}{3} & Low to moderate levels of & Salmonella typhimurium & & & \\
\hline & Shiga-like toxin & W118 & ND & 20 & Yes $(1: 6,400)$ \\
\hline & & E. coli & & & \\
\hline & & TD $514 C_{1}$ & ND & 20 & Yes $(1: 6,400)$ \\
\hline & & RDEC-1 & ND & 40 & Yes $(1: 12,800)$ \\
\hline & & $460-8-58-899$ & ND & 40 & Yes $(1: 6,400)$ \\
\hline & & E74/68 & ND & 60 & Yes $(1: 6,400)$ \\
\hline & & $\mathrm{E} 851 / 71$ & ND & 100 & Yes $(1: 6,400)$ \\
\hline & & H10407 & ND & 100 & Yes $(1: 3,200)$ \\
\hline & & $12801 / 0$ & ND & 200 & Yes $(1: 1,600)$ \\
\hline & & Shigella flexneri type & & & \\
\hline & & 2a (strain M4243) & 50 & 300 & Yes $(1: 3,200)$ \\
\hline \multirow[t]{4}{*}{4} & High levels of Shiga or & E. coli & & & \\
\hline & Shiga-like toxin & H30 & $1 \times 10^{3}$ & $1 \times 10^{4}$ & Yes $(1: 800)$ \\
\hline & & S-22-1 & $1 \times 10^{4}$ & $4 \times 10^{4}$ & Yes $(1: 3,200)$ \\
\hline & & $\begin{array}{l}\text { S. dysenteriae type } 1 \\
\text { (strain 60R) }\end{array}$ & $1 \times 10^{4}$ & $3 \times 10^{5}$ & Yes $(1: 1,600-1: 6,400)$ \\
\hline
\end{tabular}

NOTE. $\quad \mathrm{CD}_{\mathrm{s}_{0}}=$ cytotoxic doses required to kill $50 \%$ of HeLa cells; $\mathrm{ND}=$ not detected.

* Highest dilution of serum that completely protected HeLa cells from $10 \mathrm{CD}_{50}$ of toxin.

ginosa. The microbes assigned to category 2 (trace levels of Shiga-like cell-associated cytotoxin) included the two avirulent $E$. coli strains 1133 [15] and HS $[1,9]$. The agents listed in category 3 (producers of low to moderate levels of Shiga-like cytotoxins) included seven strains of $E$. coli ranging from an ST-positive strain that produced low levels of toxin (TD 514C) [22] to an enteropathogenic strain $(12801 / 0)$ that made nearly as much toxin as $S$. flexneri type $2 \mathrm{a}$. We found that $S$. $t y$ phimurium strain $\mathrm{W} 118[26,27]$ also made low levels of a cytotoxin, an observation that supports the findings of others (F. C. W. Koo and J. Peterson, personal communication). The relationship between the $S$. typhimurium cytotoxin described by these investigators and the Shiga-like toxin described in the present investigation remains to be determined.

Category 4 included two strains of $E$. coli that made levels of Shiga-like toxin equivalent to the strain 60R positive control. One of the microbes, strain $\mathrm{H} 30$, was described by Konowalchuk et al.
[18]. They reported that culture filtrates of the bacterium were cytotoxic for Vero cells. The other organism, strain S-22-1, was obtained from M. Gurwith (Michigan State University, East Lansing). Gurwith and Williams [19] observed that a culture filtrate of the strain, which was isolated from the stool of a child with diarrhea, grown in brainheart infusion broth was cytotoxic for HeLa cells. That the extracts from these two LT-negative, STnegative, Séreny test-negative strains of $E$. coli isolated from infants with diarrheal disease [18, 19] do indeed make a toxin similar to Shiga toxin was verified by other biologic and immunologic tests. Lines of identity were seen when extracts of $E$. coli strain H30, E. coli strain S-22-1, and S. dysenteriae type 1 strain $60 \mathrm{R}$ were diffused against rabbit antiserum to Shiga toxin (figure 1). Furthermore, cell extracts of these two strains of $E$. coli, like $S$. dysenteriae type 1 strain 60R, paralyzed and killed mice, inhibited protein synthesis in HeLa cells, and caused fluid accumulation in ligated rabbit ileal loops (table 3), as did fil- 
Figure 1. Results of immunodiffusion of rabbit antiserum to toxin produced by Shigella dysenteriae type 1 (center well) against crude cell extracts of $S$. dysenteriae type 1 strain 60R (well A), Escherichia coli strain $\mathrm{H} 30$ (well B), and $E$. coli strain S-22-1 (well C).

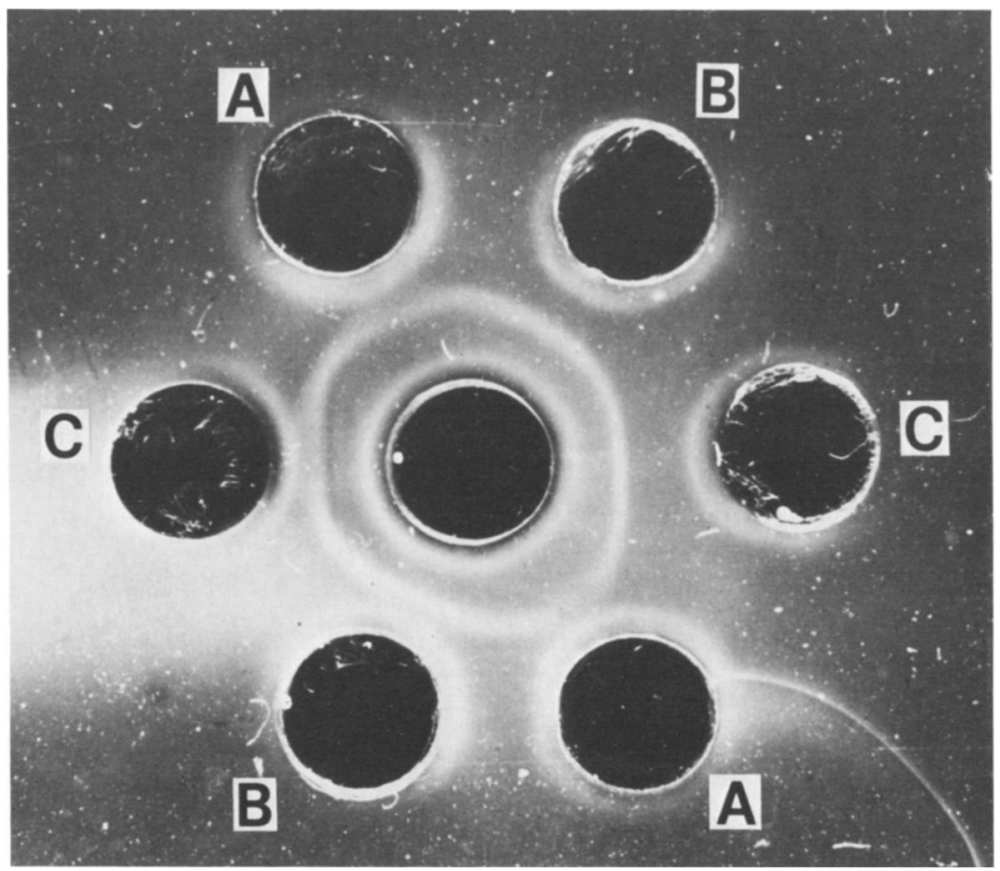

tered culture supernatants of the microbes (data not shown). By contrast, an extract of $E$. coli strain 12801/0 inhibited protein synthesis in HeLa cells but was not lethal for mice or enterotoxic for rabbits, and an extract of $E$. coli $\mathrm{K} 12$ strain 1133 was negative for all three activities. It should be noted that the mouse lethality and rabbit enterotoxicity assays for purified Shiga toxin are at least $10^{4}$ times less sensitive than are tests for cytotoxicity or inhibition of protein synthesis $[14,32]$.

\section{Discussion}

The present study established that some strains of $E$. coli make a Shiga-like toxin and showed that among such isolates toxic activity varied as much as 10,000 -fold. The basis for the diversity in yields of cell-associated toxin activity was not examined but parallels the situation seen among species of shigellae-for example, $S$. dysenteriae makes $10^{4}-10^{5}$ more cytotoxic material per milligram of cell extract protein than does $S$. flexneri $[14,25]$. Several theories may be proposed to explain the $E$. coli strain-dependent differences in elaboration of Shiga-like toxin. (I) The regulatory mechanisms that control toxin production by the organisms may be quite distinct. For example, a category 4 (high-level producer of toxin) organism may make toxin constitutively, whereas toxin levels made by $E$. coli in category 2 or 3 (trace to

Table 3. Other biologic properties of extracts of representative bacteria in a study of bacterial cytotoxins.

\begin{tabular}{|c|c|c|c|}
\hline Bacteria & $\begin{array}{c}\text { Enterotoxicity for } \\
\text { rabbits* }\end{array}$ & $\begin{array}{c}\text { Lethality for mice } \\
\text { (LD } \mathrm{LD}_{50} / \mu \mathrm{g} \\
\text { of protein) }{ }^{\dagger}\end{array}$ & $\begin{array}{c}\text { Inhibition of protein } \\
\text { synthesis ( } \mathrm{ID}_{50} / \mathrm{mg} \\
\text { of protein) }\end{array}$ \\
\hline \multicolumn{4}{|l|}{$\begin{array}{l}\text { Shigella dysenteriae type } 1 \text {, } \\
\text { strain } 60 \mathrm{R}\end{array}$} \\
\hline \multicolumn{4}{|l|}{ Escherichia coli } \\
\hline S-22-1 & Yes & Yes (60) & Yes $\left(10^{5}\right)$ \\
\hline H30 & Yes & Yes $(90)$ & Yes $\left(10^{5}\right)$ \\
\hline $12801 / 0$ & No & No & Yes $(90)$ \\
\hline $\mathrm{K} 12$, strain 1133 & No & No & No $(<10)$ \\
\hline
\end{tabular}

* Extract tested at a dilution of 1:20.

$\dagger$ Hind leg paralysis observed before death of mice.

$\ddagger_{\mathrm{ID}_{\text {s0 }}}=$ dose required to inhibit protein synthesis in HeLa cells by $50 \%$. 
moderate levels of toxin production) may be determined by a repressible or inducible mechanism. (2) Toxin made by category 2 or 3 microbes may vary structurally from that produced by category 4 bacteria. Perhaps structural differences translate to variability in biologic activities. (3) Category 2 and 3 bacteria may manufacture large amounts of biologically inactive toxin that compete with active toxin in bioassays. If the reason for variability in toxicity among strains of $E$. coli is the same as that for shigellae, the last postulate is not likely because a previous investigation [14] showed that no biologically inactive toxin was found in extracts of S. flexneri. Genetic and biochemical experiments should address this issue of variability in the quantity of Shiga-like toxin made by isolates of $E$. coli.

Two lines of circumstantial evidence suggest that the Shiga-like toxin may play a role in the pathogenesis of some cases of $E$. coli-conferred diarrhea. (I) Two strains of $E$. coli implicated as mediators of gastroenteritis in children made high levels of Shiga-like toxin but did not elaborate LT or ST and were Séreny test-negative. (2) The avirulent $E$. coli strains 1133 and HS made only trace amounts of toxin. This finding suggests that if a Shiga-like toxin is in fact a virulence determinant, then either these isolates do not make enough toxin to be detrimental or another factor or factors may be required to confer pathogenicity. Such a factor could be a mechanism of adherence to the intestinal mucosa; indeed, Smith and Linggood [33] clearly established that enterotoxigenic strains of $E$. coli that lack the K88 colonizing factor fail to cause diarrheal disease in pigs. That some LT-positive, ST-positive, or enteroinvasive strains of $E$. coli also made low to moderate amounts of Shiga-like toxin (table 2) does not rule out a role for Shiga-like toxin in disease caused by $E$. coli. Rather, enterotoxic strains such as E. coli strain H10407 may colonize a region of the intestine where Shiga-like toxin is ineffective. Alternatively, Shiga-like toxin may actively contribute to the development of clinical manifestations in E. coli strain H14047-induced diarrhea. Obviously, further studies are required to define the role (if any) of Shiga-like toxin in the pathogenesis of diarrhea. These investigations could include an examination of whether the toxin functions in vivo as an enterotoxin or as a cytotoxin.

The structural relationship between Shiga and
Shiga-like toxins was not examined in this investigation. The fact that Shiga-like toxic activity can be neutralized by antiserum to purified Shiga toxin suggests some degree of homology between the toxins. Other data that support the hypothesis that the molecules are physically similar include the range of biologic activities of the two moieties and the immunodiffusion results. Shiga toxin appears to be composed of two subunits: an enzymatically active A subunit ( $\sim 30,500$ daltons) that when nicked and reduced inactivates $60 \mathrm{~S}$ ribosomes and inhibits peptide chain elongation and six or more copies of a B subunit ( $\sim 5,000$ daltons) that is presumed to function in the binding of toxin to the target cell $[34,35]$. Thus, Shiga-like toxins probably contain one or both of these components. Purification of the toxic material from $E$. coli strain $\mathrm{H} 30$ should clarify this issue.

\section{References}

1. DuPont, H. L., Formal, S. B., Hornick, R. B., Snyder, M. J., Libonati, J. P., Sheahan, D. G., LaBrec, E. H., Kalas, J. P. Pathogenesis of Escherichia coli diarrhea. N. Engl. J. Med. 285:1-9, 1971.

$\rightarrow$ Gyles, C. L. Heat-labile and heat-stable forms of the enterotoxin from $E$. coli strains enteropathogenic for pigs. Ann. N.Y. Acad. Sci. 176:314-322, 1971.

$\rightarrow$ Gyles, C. L., Barnum, D. A. A heat-labile enterotoxin from strains of Escherichia coli enteropathogenic for pigs. J. Infect. Dis. 120:419-426, 1969.

4. Smith, H. W., Gyles, C. L. The relationship between two apparently different enterotoxins produced by enteropathogenic strains of Escherichia coli of porcine origin. J. Med. Microbiol. 3:387-401, 1970.

5. Ogawa, H., Nakamura, A., Sakazaki, R. Pathogenic properties of "enteropathogenic" Escherichia coli from diarrheal children and adults. Jpn. J. Med. Sci. Biol. 21:333-349, 1968.

6. Séreny, B. Experimental shigella keratoconjunctivitis; a preliminary report. Acta Microbiol. Acad. Sci. Hung. 2:293-296, 1955.

7. Sakazaki, R., Tamura, K., Saito, M. Enteropathogenic Escherichia coli associated with diarrhea in children and adults. Jpn. J. Med. Sci. Biol. 20:387-399, 1967.

$\rightarrow$ Cantey, J. R., Blake, R. K. Diarrhea due to Escherichia coli in the rabbit: a novel mechanism. J. Infect. Dis. 135:454-462, 1977.

9. Levine, M. M., Berquist, E. J., Nalin, D. R., Waterman, D. H., Hornick, R. B., Young, C. R., Sotman, S., Rowe, B. Escherichia coli strains that cause diarrhoea but do not produce heat-labile or heat-stable enterotoxins and are non-invasive. Lancet 1:1119-1122, 1978.

10. Ulshen, M. H., Rollo, J. L. Pathogenesis of Escherichia coli gastroenteritis in man-another mechanism. N. Engl. J. Med. 302:99-101, 1980. 
11. Polotsky, Y. E. Enteral challenge of animals with enteropathogenic Escherichia coli. Experiments on isolated intestinal loops. In M. V. Voino-Yasenetsky and T. Bakas [ed.]. Pathogenesis of intestinal infections. Akademiai Kiado, Budapest, 1977, p. 296-323.

12. Takeuchi, A., Inman, L. R., O'Hanley, P. D., Cantey, J. R., Lushbaugh, W. B. Scanning and transmission electron microscopic study of Escherichia coli 015 (RDEC-1) enteric infection in rabbits. Infect. Immun. 19:686-694, 1978.

13. O'Brien, A. D., Thompson, M. R., Cantey, J. R., Formal, S. B. Production of a Shigella dysenteriae-like toxin by pathogenic Escherichia coli [abstract no. B103]. In Abstracts of the annual meeting. American Society for Microbiology, Washington, D.C., 1977.

14. O'Brien, A. D., LaVeck, G. D. Immunochemical and cytotoxic activities of Shigella dysenteriae 1 (Shiga) and Shiga-like toxins. Infect. Immun. 35:1151-1154, 1982.

15. Formal, S. B., Gemski, P., Jr., Baron, L. S., LaBrec, E. H. Genetic transfer of Shigella flexneri antigens to Escherichia coli K-12. Infect. Immun. 1:279-287, 1970.

16. Kennedy, D. H., Walker, G. H., Fallon, R. J., Boyd, J. F., Gross, R. J., Rowe, B. An outbreak of infantile gastroenteritis due to Escherichia coli O142. J. Clin. Pathol. 26:731-737, 1973.

17. Klipstein, F. A., Rowe, B., Engert, R. F., Short, H. B., Gross, R. J. Enterotoxigenicity of enteropathogenic serotypes of Escherichia coli isolated from infants with epidemic diarrhea. Infect. Immun. 21:171-178, 1978.

18. Konowalchuk, J., Spiers, J. I., Stavric, S. Vero response to a cytotoxin of Escherichia coli. Infect. Immun. 18:775-779, 1977.

$\rightarrow$ Gurwith, M. J., Williams, T. W. Gastroenteritis in children: a two-year review in Manitoba. I. Etiology. J. Infect. Dis. 136:239-247, 1977.

20. Evans, D. J., Jr., Evans, D. G., Gorbach, S. L. Production of vascular permeability factor by enterotoxigenic Escherichia coli isolated from man. Infect. Immun. 8:725-730, 1973.

21. Lumish, R. M., Ryder, R. W., Anderson, D. C., Wells, J. G., Puhr, N. D. Heat-labile enterotoxigenic Escherichia coli induced diarrhea aboard a Miami-based cruise ship. Am. J. Epidemiol. 111:432-436, 1980.

22. Merson, M. H., Morris, G. K., Sack, D. A., Wells, J. G., Feeley, J. C., Sack, R. B., Creech, W. B., Kapikian, A. Z., Gangarosa, E. J. Travelers' diarrhea in Mexico: a prospective study of physicians and family members attending a congress. N. Engl. J. Med. 294:1299-1305, 1976.

23. O'Brien, A. D., LaVeck, G. D., Griffin, D. E., Thompson, M. R. Characterization of Shigella dysenteriae 1 (Shiga) toxin purified by anti-Shiga toxin affinity chromatography. Infect. Immun. 30:170-179, 1980.

24. Dubos, R. J., Geiger, J. W. Preparation and properties of Shiga toxin and toxoid. J. Exp. Med. 84:143-156, 1946.

25. O'Brien, A. D., Thompson, M. R., Gemski, P., Doctor, B. P., Formal, S. B. Biological properties of Shigella flexneri $2 \mathrm{~A}$ toxin and its serological relationship to Shigella dysenteriae 1 toxin. Infect. Immun. 15:796798, 1977.

26. Kent, T. H., Formal, S. B., LaBrec, E. H. Acute enteritis due to Salmonella typhimurium in opium-treated guinea pigs. Archives of Pathology 81:501-508, 1966.

27. Giannella, R. A., Formal, S. B., Dammin, G. J., Collins, H. Pathogenesis of salmonellosis: studies of fluid secretion, mucosal invasion, and morphologic reaction in the rabbit ileum. J. Clin. Invest. 52:441-453, 1973.

28. Layne, E. Spectrophotometric and turbidimetric methods for measuring proteins. Methods Enzymol. 3:447-454, 1957.

29. Gentry, M. K., Dalrymple, J. M. Quantitative microtiter cytotoxicity assay for shigella toxin. J. Clin. Microbiol. 12:361-366, 1980.

30. Formal, S. B., Kundel, D., Schneider, H., Kunev, N., Sprinz, H. Studies with Vibrio cholerae in the ligated loop of the rabbit. Br. J. Exp. Pathol. 42:504-510, 1961.

31. Brown, J. E., Rothman, S. W., Doctor, B. P. Inhibition of protein synthesis in intact HeLa cells by Shigella dysenteriae 1 toxin. Infect. Immun. 29:98-107, 1980.

32. Brown, J. E., Griffin, D. E., Rothman, S. W., Doctor, B. P. Purification and biological characterization of Shiga toxin from Shigella dysenteriae 1. Infect. Immun. 36:996-1005, 1982.

33. Smith, H. W., Linggood, M. A. Observations on the pathogenic properties of the K88, HLY and ENT plasmids of Escherichia coli with particular reference to porcine diarrhoea. J. Med. Microbiol. 4:467-485, 1971.

34. Olsnes, S., Reisbig, R., Eiklid, K. Subunit structure of Shigella cytotoxin. J. Biol. Chem. 256:8732-8738, 1981.

35. Reisbig, R., Olsnes, S., Eiklid, K. The cytotoxic activity of shigella toxin. J. Biol. Chem. 256:8739-8744, 1981. 